small, and a larger series of patients is needed to estimate the size and persistence of the excess more precisely. It will be interesting to determine from such a series if there is also an excess of soft tissue sarcomas and squamous cell cancer of the skin, which are also increased in incidence in renal transplant patients.

We are grateful to Neville Selwood, of the European Dialysis and Transplant Association, for providing data on our patients; Andy Scott for help with the analysis; Sir Richard Doll and Julian Peto for valuable suggestions; and the Cancer Research Campaign for financial support.

Requests for reprints should be addressed to L J Kinlen.

\section{References}

${ }^{1}$ Hoover R, Fraumeni JF Jr. Risk of cancer in renal transplant recipients. Lancet 1973;ii:55-7.

${ }^{2}$ Kinlen LJ, Sheil AGR, Peto J, Doll R. Collaborative United KingdomAustralasian study of cancer in patients treated with immunosuppressive drugs. $B r$ Med f 1969 ;ii :1461-6.

${ }^{3}$ Matas AJ, Simmons RL, Kjellstrand CM, Buselmeier TJ, Najarian JS. Increased incidence of malignancy during chronic renal failure. Lancet 1975 ;ii: $883-6$

4 Penn I, Starzl TE. Malignant tumors arising de novo in immunosuppressed organ transplant recipients. Transplantation 1972;14:407-17.

${ }^{5}$ Hurwich BJ, Chait A, Dollberg M, Dollberg L. Malignancy in chronic renal failure. Lancet 1975 ;ii :717.

${ }^{6}$ Miach PJ, Dawborn JK, Xipell J. Neoplasia in patients with chronic renal failure on long-term dialysis. Clin Nephrol 1976;5:101-4.

${ }^{7}$ Sutherland GA, Glass J, Gabriel R. Increased incidence of malignancy in chronic renal failure. Nephron 1977;18:182-4.
${ }^{8}$ Matas AJ, Simmons RL, Kjellstrand CM, Buselmeier TJ, Johnson TL, Najarian JS. Increased incidence of malignancy in uraemic patients and its significance to transplantations. Transplant Proc 1977;9:1137-40.

9 Waterhouse JAH. Cancer handbook of epidemiology and prognosis. Edinburgh and London:Churchill Livingstone, 1974.

${ }^{10}$ Bengtsson U, Angervall L, Ekman H, Lehmann L. Scand $\mathcal{F}$ Urol Nephrol $1968 ; 2: 145$.

${ }^{11}$ Dunnill MS, Millard PR, Oliver D. Acquired cystic disease of the kidneys: a hazard of long-term intermittent maintenance haemodialysis. $\mathcal{F}$ Clin Pathol 1977;30:868-77.

12 Tasker PRW, Walden PAM, Gower PE, Bagshawe KD. Reticulosarcoma occurring during long-term haemodialysis. Clin Nephrol 1975;3:28-30.

${ }^{13}$ Bichel J, Jensen KB. Nephrotic syndrome and Hodgkin's disease. Lancet 1971 ;ii:1425-6.

${ }^{14}$ Hansen HE, Skov PE, Askjaer SA, Albertsen K. Hodgkin's disease associated with the nephrotic syndrome without kidney lesion. Acta Med Scand 1972;191:307-13.

${ }^{15}$ Sherman RL, Susin M, Weksler ME, Becker EL. Lipoid nephrosis in Hodgkin's disease. Am $\mathcal{F}$ Med 1972;52:699-706.

${ }^{16}$ Froom DW, Franklin WA, Hano JE, Potter EV. Immune deposits in Hodgkin's disease with nephrotic syndrome. Archives of Pathology 1972; 94:547-53.

17 Routledge RC, Hann IM, Jones PHM. Hodgkin's disease complicated by the nephrotic syndrome. Cancer $1976 ; 38: 1735-40$.

${ }^{18}$ Moorthy AV, Simmerman ST, Burkholder PM. Nephrotic syndrome in Hodgkin's disease. Am $\mathcal{F}$ Med 1976;61:471-7.

${ }^{19}$ Couser W, Badger A, Cooperband S, et al. Hodgkin's disease and lipoid nephrosis. Lancet $1977 ; \mathrm{i}: 912-3$.

${ }^{20}$ Slifkin RF, Goldberg J, Neff MS, Baez A, Mattoo N, Güpta S. Malignancy in end-stage renal disease. Trans Am Soc Artif Intern Organs 1977;23 34-9.

${ }^{21}$ Birkeland SA. Uremia as a state of immune deficiency. Scand $\mathcal{F}$ Immunol 1976;5:107-15.

(Accepted 24 March 1980)

\title{
Alcohol consumption and premature death in middle-aged men
}

\author{
BO PETERSON, HANS KRISTENSON, NILS H STERNBY, ERIK TRELL, \\ GÖRAN FEX, BERTIL HOOD
}

\section{Summary and conclusions}

All the men living in Malmö born in 1926-9 were invited for a screening examination which included an assessment of alcohol consumption and measurement of gammaglutamyltransferase (GGT) activity. They were followed for up to four years (median 2) and their mortality assessed. Sixty-two deaths occurred, $41(0.9 \%)$ among the 4571 men who attended the screening investigation and $21(1.3 \%)$ among the 1609 who did not respond to the invitation. Evidence of alcohol abuse or an alcoholrelated cause of death was present in $25(61 \%)$ of the deaths among the attenders and $13(62 \%)$ of those among the non-responders. GGT values at the screening investi-

\footnotetext{
Section of Preventive Medicine, Departments of Internal Medicine, Alcohol Diseases, Pathology, and Clinical Chemistry, University of Lund, Malmö General Hospital, S-214 01 Malmö, Sweden BO PETERSON, MD, associate researcher in preventive medicine HANS KRISTENSON, MD, associate researcher in alcohol diseases NILS H STERNBY, MD, professor of pathology

ERIK TRELL, $M D$, associate professor of preventive medicine GÖRAN FEX, MD, associate professor of clinical chemistry BERTIL HOOD, MD, professor of medicine
}

gation were significantly increased in $19(46 \%)$ of those who died, but established risk factors, such as cholesterol and triglyceride concentrations and blood pressure, had little predictive value.

Measurement of GGT provided an objective index of alcohol consumption, though the full clinical importance of a raised value needs further assessment. The finding that heavy alcohol consumption was the single most important factor associated with premature death in these middle-aged men has important implications for prevention.

\section{Introduction}

Though alcohol is recognised to be a major contributory factor in disease and premature death among middle-aged men, the medical profession still tends to underestimate the importance of alcohol in the range of disease. ${ }^{1}$ There have been demands for a "public health strategy" to identify and prevent alcohol abuse through screening ${ }^{2}$. and for powerful political and economic measures to curb consumption. An important prerequisite for any of these measures is increased knowledge of the medical complications of alcohol consumption.

We established a screening clinic to try to identify and prevent alcohol abuse, and we report here a study on the short-term mortality of middle-aged men who were invited for screening. 


\section{Subjects and methods}

Screening-A section of preventive medicine was established in autumn 1974 within the medical clinic at Malmö General Hospital. Total male birth-year cohorts in Malmö were invited to a screening investigation, where they underwent measurements of height and weight, pulse rate, blood pressure (standing and recumbent and before and after 10 minutes' rest), and skinfold thickness; simple pulmonary function tests; electrocardiography; and several fasting laboratory estimates, including $\gamma$-glutamyltransferase (GGT). All laboratory analyses were performed according to standard methods in the hospital's department of clinical chemistry. GGT was analysed according to the recommendation of the Scandinavian Enzyme Committee. ${ }^{4}$ The usual laboratory upper limit of normal for GGT was $1.0 \mu \mathrm{kat} / \mathrm{l}$, but in our screening clinic we used $1.44 \mu \mathrm{kat} / 1$ as a cut-off limit for further investigation. Attenders were also asked to fill in a questionnaire on their alcohol intake. Findings at the screening investigation were checked one or two weeks later and if confirmed the patient was invited for further investigation and treatment at special outpatient clinics within the department of preventive medicine. These included clinics for blood pressure, lipids, "borderline diabetes," and raised GGT values. ${ }^{4}$

Study of population-Screening started in November 1974 with men born in 1926. Subsequent birth-year cohorts of men were examined consecutively in the following years together with women and a few younger birth-year cohorts. At the end of 1978 all men living in Malmö who were born in 1926-9 had been invited for screening-a total of 6180 . Of these, $4571(74 \%)$ responded. All the men were aged 48 or 49 years at the screening investigation, and they were followed-up for up to four years (median two years).

Mortality-Information on deaths occurring after the invitation to screening in these birth-year cohorts was obtained from a register at the department of pathology, Malmö General Hospital. This register covers all deaths in Malmö, including those where necropsy is not performed. There were $41(0.9 \%)$ deaths among the 4571 men who attended for screening and $21(1.3 \%)$ among the 1609 who did not. The necropsy rate was $90 \%$ (36/41) among attenders and $100 \%$ among the non-responders.

Alcohol consumption-To assess the part that alcohol consumption may have played in each death all accessible information on the deaths was reviewed: protocols from screening death certificates, necropsy reports, police reports, and hospital records, including those of the alcohol clinic of Malmö General Hospital. The men who died were classified as having an alcohol-positive history if this information showed at least one of the following: $(a)$ a history of heavy alcohol consumption; (b) registration at the alcohol clinic; $(c)$ a raised GGT value at the screening investigation which, after interview with one of us $(\mathrm{HK})$, was considered to be due to heavy drinking. ${ }^{4}$ Those men who did not fulfill these criteria included a few who had only scanty or inconclusive information. All deaths from medical complications of alcoholism-for example, cirrhosis of the liver, oesophageal varices, and alcohol intoxication-and cases where alcohol intoxication contributed to the death according to necropsy reports were classified as probable alcohol-related deaths. Deaths from conditions that may have been related to alcohol consumption were classified as possible alcohol-related deaths.

\section{Results}

Table I shows causes of death, GGT values, and histories of alcohol consumption and smoking in the attenders at the screening clinic. Nineteen men had raised GGT activities and 21 a history of heavy alcohol consumption. These findings are related to the main causes of death in table II : raised GGT values and history of alcohol consumption were particularly prominent among men who committed suicide or died in accidents and those who died of miscellaneous causes (which included cirrhosis of the liver, bleeding oesophageal varices, etc).

Table III shows the causes of death according to the death certificates and a retrospective classification of alcohol consumption among non-responders. Mortality after the date of invitation to screening among non-responders was almost one and a half times that among attenders $(1.3 \%$ compared with $0.9 \%)$. A directly alcohol-related cause of death was found in 10 of the 21 cases and a positive history of heavy alcohol consumption in $13(62 \%)$.

There was a lower incidence of cardiovascular deaths, a higher

TABLE I-Cause of death, alcohol and smoking history, and other findings at screening investigation in 41 participants who later died

\begin{tabular}{|c|c|c|c|c|c|c|c|}
\hline $\begin{array}{l}\text { Case } \\
\text { No }\end{array}$ & Cause of death & $\underset{(\mu \mathrm{kat} / 1)}{\mathrm{GGT}}$ & $\begin{array}{c}\text { History } \\
\text { of } \\
\text { heavy } \\
\text { alcohol } \\
\text { intake }\end{array}$ & $\begin{array}{l}\text { History } \\
\text { of } \\
\text { smoking }\end{array}$ & Other screening findings* & $\begin{array}{c}\text { Time } \\
\text { between } \\
\text { investigation } \\
\text { and death } \\
(\mathrm{yr})\end{array}$ & $\begin{array}{c}\text { Alcohol- } \\
\text { related } \\
\text { death }\end{array}$ \\
\hline \multirow{5}{*}{$\begin{array}{l}1 \\
2 \\
3 \\
4 \\
5 \\
6 \\
7\end{array}$} & \multirow{5}{*}{$\begin{array}{l}\text { Malignant glioma } \\
\text { Cardiac hypertrophy, alcohol intoxication } \\
\text { Alcohol and barbiturate intoxication } \\
\text { Malignant histiocytosis } \\
\text { Pancreas cancer } \\
\text { Alcohol intoxication } \\
\text { Train accident (engine-driver) }\end{array}$} & \multirow{5}{*}{$\begin{array}{l}0.42 \\
1.93 \\
2.33 \\
2.98 \\
1.84 \\
8.14 \\
2.42\end{array}$} & - & + & \multirow{3}{*}{$\mathrm{BP}$ (diastolic) $105 \mathrm{~mm} \mathrm{Hg}$} & \multirow{4}{*}{$\begin{array}{l}1 \\
2 \\
1 \frac{1}{2} \\
1 \frac{1}{2} \\
1 \\
1\end{array}$} & \multirow{4}{*}{$\begin{array}{l}\text { Probable } \\
\text { Probable } \\
\text { Possible } \\
\text { Probable }\end{array}$} \\
\hline & & & $\begin{array}{l}+ \\
+\end{array}$ & $\stackrel{t}{+}$ & & & \\
\hline & & & + & + & & & \\
\hline & & & + & $\stackrel{+}{+}$ & \multirow{2}{*}{$\begin{array}{l}\text { Triglyceride } 2.8 \mathrm{mmol} / 1 \\
\text { Triglyceride } 3.5 \mathrm{mmol} / 1 \text {, relative body } \\
\text { weight } 1.4\end{array}$} & & \\
\hline & & & + & - & & \multirow[b]{2}{*}{$\frac{1}{\frac{1}{2}} \mathrm{mnth}_{2}$} & \multirow{2}{*}{$\begin{array}{l}\text { Possible } \\
\text { Probable }\end{array}$} \\
\hline \multirow{6}{*}{$\begin{array}{r}8 \\
9 \\
10 \\
11 \\
12 \\
13 \\
14 \\
15 \\
16\end{array}$} & $\begin{array}{l}\text { Ethanol and hexapropymate intoxication } \\
\text { Cor pulmonale }\end{array}$ & $\begin{array}{l}0.82 \\
0.46\end{array}$ & \pm & $\stackrel{+}{\mathrm{NA}}$ & PF $2.11 / \mathrm{min}$, FVC 0.71 & & \\
\hline & \multirow{2}{*}{$\begin{array}{l}\text { Liver cirrhosis, chronic alcoholism } \\
\text { Bronchial cancer }\end{array}$} & \multirow{2}{*}{$\begin{array}{l}0.60 \\
1.77\end{array}$} & ‡ & $\stackrel{+}{+}$ & \multirow{2}{*}{ Relative body weight $2 \cdot 2$} & \multirow{2}{*}{$\begin{array}{l}\frac{1}{2} \\
2 \frac{1}{2}\end{array}$} & \multirow{2}{*}{ Probable } \\
\hline & & & \pm & $\mathrm{NA}^{+}$ & & & \\
\hline & $\begin{array}{l}\text { Alcoholic cardiomyopathy } \\
\text { Pancreatitis }\end{array}$ & $\begin{array}{l}1 \cdot 11 \\
3 \cdot 22\end{array}$ & $\begin{array}{l}+ \\
+\end{array}$ & $\begin{array}{l}+ \\
+\end{array}$ & $\mathrm{Hb} 114 \mathrm{~g} / \mathrm{dl}$, glucose $8.6 \mathrm{mmol} / 1$ & $\begin{array}{ll}21 \\
2\end{array}$ & $\begin{array}{l}\text { Probable } \\
\text { Probable }\end{array}$ \\
\hline & \multirow{2}{*}{$\begin{array}{l}\text { Diffuse abdominal adenocarcinoma } \\
\text { Pulmonary embolism } \\
\text { Myocardial infarction }\end{array}$} & 0.30 & 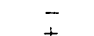 & + & & 22 & \multirow{2}{*}{ Probable } \\
\hline & & $\begin{array}{l}0.74 \\
1.94\end{array}$ & \pm & + & \multirow{2}{*}{\multicolumn{2}{|c|}{$\begin{array}{l}\mathrm{Hb} 108 \mathrm{~g} / \mathrm{dl}, \mathrm{ESR} 89 \mathrm{mmol} / 1 \\
\text { Relative body weight } 1.4 \text {, glucose } 7.9 \mathrm{mmol} / 1\end{array}$}} & \\
\hline 18 & $\begin{array}{l}\text { Myocardralintarction } \\
\text { Liver cirrhosis }\end{array}$ & 31.7 & + & + & & & Probable \\
\hline 19 & $\begin{array}{l}\text { Myocardial fibrosis } \\
\text { Pulmonary embolism }\end{array}$ & 0.91 & + & 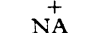 & \multirow{2}{*}{\multicolumn{2}{|c|}{ Glucose $7 \cdot 2 \mathrm{mmol} / 1$}} & \multirow{3}{*}{$\begin{array}{l}\text { Probable } \\
\text { Probable }\end{array}$} \\
\hline 21 & \multirow{2}{*}{$\begin{array}{l}\text { Duodenal rupture (traumatic ?) } \\
\text { Dissecting aortic aneurysm }\end{array}$} & $\begin{array}{l}1.58 \\
0.79\end{array}$ & + & + & & & \\
\hline 22 & & 0.53 & - & + & BP $215 / 135 \mathrm{~mm} \mathrm{Hg}$ & $1 \mathrm{mnth}$ & \\
\hline 24 & $\begin{array}{l}\text { Myocardialinfiarction } \\
\text { Pancreatic neoplasm }\end{array}$ & $\begin{array}{l}1.86 \\
0.47\end{array}$ & $\stackrel{+}{+}$ & + & & 4 & \multirow[t]{5}{*}{ Possible } \\
\hline 25 & Coronary sclerosis & 0.35 & - & + & & & \\
\hline $\begin{array}{l}26 \\
27\end{array}$ & $\begin{array}{l}\text { Chronic myeloid leukaemia } \\
\text { Cardiosclerosis, diabetes }\end{array}$ & $\begin{array}{l}5.15 \\
1.93\end{array}$ & $\overline{3}$ & $\overline{\mathrm{NA}}$ & $\begin{array}{l}\text { WBC } 59 \times 10^{9} 1 \\
\text { Triglyceride } 3.1 \mathrm{mmol} / 1 \mathrm{glucose} 7.3 \mathrm{mmol} / 1\end{array}$ & 3 & \\
\hline 28 & Malignant melanoma & 0.84 & - & & & 2 & \\
\hline & Systemic hypertension & $1 \cdot($ & + & + & 1.5 ; creatinine $438 \mu \mathrm{mol} / 1$ & $2 \frac{1}{2}$ & \\
\hline $\begin{array}{l}30 \\
31\end{array}$ & $\begin{array}{l}\text { Bronchial cancer } \\
\text { Pancreatic neoplasm }\end{array}$ & $\begin{array}{l}0 \cdot 72 \\
0.79\end{array}$ & $\overline{-}$ & \pm & Relative body weight 1.4 & $\begin{array}{l}2 \frac{2}{2} \\
2 \frac{1}{2}\end{array}$ & \\
\hline 32 & Cardiosclerosis & 0.75 & - & + & $\mathrm{BP} 170 / 115 \mathrm{~mm} \mathrm{Hg}$ & 3 & \\
\hline 33 & Myelitis, myocarditis & 0.33 & 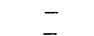 & $\mp$ & BP $190 / 115 \mathrm{~mm} \mathrm{Hg}$, relative body weight $1 \cdot 6$ & $2^{\frac{1}{2}}$ & \\
\hline 35 & $\begin{array}{l}\text { Cerebral haemorrhage } \\
\text { Myocardial infarction }\end{array}$ & $\begin{array}{l}0.00 \\
1.33\end{array}$ & - & - & $\mathrm{BP} 155 / 110 \mathrm{~mm} \mathrm{Hg}$ & 2 & \\
\hline $\begin{array}{l}36 \\
37\end{array}$ & $\begin{array}{l}\text { Cardiosclerosis } \\
\text { Cardiosclerosis }\end{array}$ & $\begin{array}{l}2.59 \\
0.56\end{array}$ & \pm & $\stackrel{+}{-}$ & $\mathrm{BP} 165 / 115 \mathrm{~mm} \mathrm{Hg}$ & 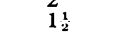 & \\
\hline 38 & Bleeding oesophagal varices & 2.96 & + & + & BP $175 / 105 \mathrm{~mm} \mathrm{Hg}$, glucose $8.2 \mathrm{mmol} / 1$ & 2 & Probable \\
\hline 39 & Bronchopneumonia & $\begin{array}{l}3.19 \\
0.44\end{array}$ & \pm & $\stackrel{+}{+}$ & $\begin{array}{l}\text { Triglyceride } 3.1 \mathrm{mmol} / \mathrm{l}, \mathrm{gl} \\
\text { Operated angina pectoris } 19\end{array}$ & & Possible \\
\hline $\begin{array}{l}40 \\
41\end{array}$ & $\begin{array}{l}\text { Myocardialinfiarction } \\
\text { Myocardial infarction, diabetes }\end{array}$ & $\begin{array}{l}0.44 \\
0.56\end{array}$ & $\overline{-}$ & + & Known diabetes with complications & 2 & \\
\hline
\end{tabular}

*Recumbent blood pressure (BP) was measured after 10 minutes' rest. Relative body weight $=$ actual weight $/$ ideal weight for age, sex, and height. $\mathrm{PF}=\mathrm{Peak}$ flow. $\mathrm{FVC}=\mathrm{Forced}$ vital capacity. ESR = Erythrocyte sedimentation rate. Glucose value was that measured at 120 minutes during glucose tolerance test. WBC = White blood count.

Conversion: SI to traditional units-GGT: 1 k kat $/ 1 \approx 60 \mathrm{iu} / 1$. Triglyceride $: 1 \mathrm{mmol} / 1 \approx 89 \mathrm{mg} / 100 \mathrm{ml}$. Glucose: $1 \mathrm{mmol} / 1 \approx 18 \mathrm{mg} / 100 \mathrm{ml}$. 
incidence of alcohol-related deaths, and a higher incidence of attendance at the alcoholic clinic among the non-responders than among those who attended the screening clinic (table IV). Nevertheless, over half the attenders had a history of heavy alcohol consumption and about half had raised GGT activities. Altogether $25(61 \%)$ of the attenders had a history of alcohol consumption or raised GGT values, or both.

Table $\mathrm{V}$ shows that the premature deaths among attenders were

TABLE II-Causes of death among participants and non-responders according to GGT activities and alcohol history

\begin{tabular}{|c|c|c|c|c|c|c|c|}
\hline & \multicolumn{3}{|c|}{ Participants } & \multicolumn{2}{|c|}{$\begin{array}{l}\text { Non- } \\
\text { responders }\end{array}$} & \multicolumn{2}{|c|}{ Total } \\
\hline & No & $\begin{array}{c}\text { No } \\
\text { with } \\
\text { raised } \\
\text { GGT }\end{array}$ & $\begin{array}{c}\text { No } \\
\text { with } \\
\text { history } \\
\text { of } \\
\text { heavy } \\
\text { alcohol } \\
\text { intake }\end{array}$ & No & $\begin{array}{c}\text { No } \\
\text { with } \\
\text { history } \\
\text { of } \\
\text { heavy } \\
\text { alcohol } \\
\text { intake }\end{array}$ & No & $\begin{array}{c}\text { No } \\
\text { with } \\
\text { history } \\
\text { of } \\
\text { heavy } \\
\text { alcohol } \\
\text { intake }\end{array}$ \\
\hline $\begin{array}{l}\text { Cardiovascular diseases } \\
\text { Cerebrovascular diseases } \\
\text { Miscellaneous causes } \\
\text { Malignant neoplasms } \\
\text { Suicide/accidents }\end{array}$ & $\begin{array}{r}15 \\
1 \\
10 \\
10 \\
5\end{array}$ & $\begin{array}{l}6 \\
0 \\
6 \\
4 \\
3\end{array}$ & $\begin{array}{l}6 \\
0 \\
8 \\
3 \\
4\end{array}$ & $\begin{array}{l}5 \\
2 \\
9 \\
1 \\
4\end{array}$ & $\begin{array}{l}4 \\
1 \\
5 \\
1 \\
2\end{array}$ & $\begin{array}{r}20 \\
3 \\
19 \\
11 \\
9\end{array}$ & $\begin{array}{r}10 \\
1 \\
13 \\
4 \\
6\end{array}$ \\
\hline Total .. & 41 & 19 & 21 & 21 & 13 & 62 & 34 \\
\hline
\end{tabular}

TABLE III-Causes of death and history of alcohol consumption in non-responders

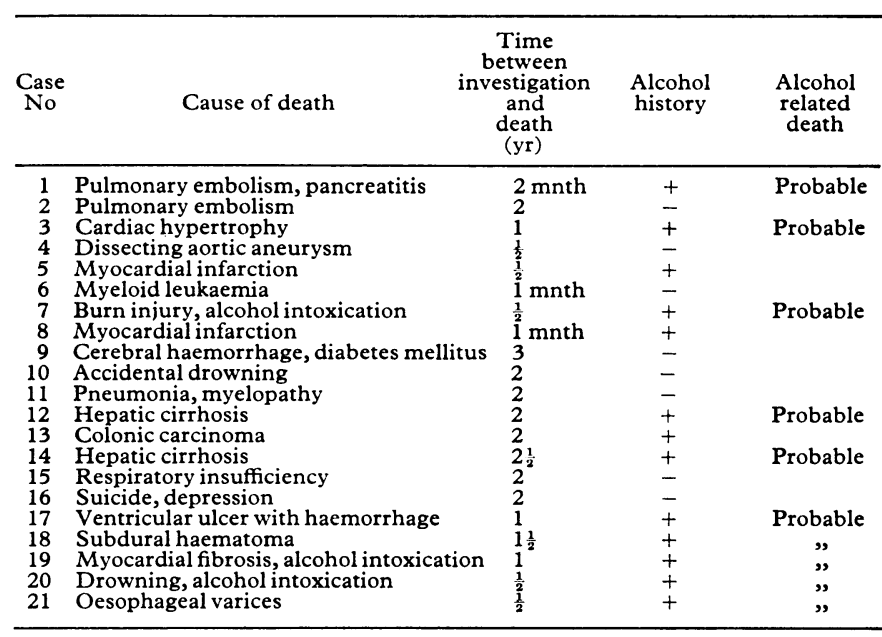

TABLE IV-Comparison between attenders and non-responders. Results are numbers of subjects

\begin{tabular}{|c|c|c|c|}
\hline & Participants & $\begin{array}{l}\text { Non- } \\
\text { responders }\end{array}$ & Total \\
\hline \multirow{3}{*}{$\begin{array}{l}\text { Relative mortality } \\
\text { Raised screening GGT }(\geqslant 1 \cdot 4) \ldots \\
\text { Known at alcohol clinic.. } \\
\text { Alcoholic history } \\
\text { Probable alcohol-related death } \\
\text { Possible alcohol-related death }\end{array}$} & \multirow{3}{*}{$\begin{array}{l}0 \cdot 9 \%(1) \\
19 / 41 \\
11 / 41 \\
21 / 41 \\
12 / 41 \\
4 / 41 \\
36 / 41\end{array}$} & $1 \cdot 3 \%(1.45)$ & $1 \%$ \\
\hline & & $\begin{array}{r}9 / 21 \\
13 / 21 \\
10 / 21\end{array}$ & $\begin{array}{l}20 / 62(32 \%) \\
34 / 62(55 \%) \\
22 / 62(36 \%)\end{array}$ \\
\hline & & $21 / 21$ & $57 / 62(92 \%)$ \\
\hline
\end{tabular}

TABLE V-Numbers of deaths among participants according to GGT activities, serum cholesterol and triglyceride concentrations, recumbent diastolic blood pressure after 10 minutes' rest, and serum urate values. Quintiles are derived from distribution of values among all participants screened in 1926-9 birth-year cohorts $(n=4571)$

\begin{tabular}{|c|c|c|c|c|c|}
\hline $\begin{array}{l}\text { GGT ( } \mu \text { kat/l) } \ldots \\
\text { No of deaths } \ldots \\
\text { Cholesterol (mmol/l) } \\
\text { No of deaths } \ldots \\
\text { Triglyceride (mmol/l) } \\
\text { No of deaths } \ldots \\
\text { Diastolic blood pressur }\end{array}$ & $\begin{array}{ll}\because & \leqslant 0 \cdot 4 \\
\therefore & 3 \\
\therefore & \leqslant 5 \cdot 0 \\
\therefore & 12 \\
\therefore & \leqslant 1 \cdot 0 \\
\therefore & 13\end{array}$ & $\begin{array}{l}-0.52 \\
5 \\
-5 \cdot 5 \\
11 \\
-1 \cdot 25 \\
3\end{array}$ & $\begin{array}{l}-0 \cdot 67 \\
4 \\
-6 \cdot 1 \\
-7 \\
-1 \cdot 50 \\
5\end{array}$ & $\begin{array}{l}-0 \cdot 96 \\
9 \\
-6 \cdot 8 \\
5 \\
-2 \cdot 02 \\
10\end{array}$ & $\begin{array}{l}\geqslant 0.97 \\
20 \\
\geqslant 6.9 \\
\quad 6 \\
\geqslant 2.03 \\
9\end{array}$ \\
\hline $\begin{array}{ll}\text { (mm Hg) } & \cdots \\
\text { No of deaths } & \cdots \\
\text { Urate }(\mu \mathrm{mol} / 1) & \cdots \\
\text { No of deaths } & \cdots\end{array}$ & $\begin{array}{l}\ldots \leqslant 75 \\
\ldots \quad 6 \\
\ldots \leqslant 257 \\
\ldots\end{array}$ & $\begin{array}{r}-85 \\
12 \\
-292 \\
8\end{array}$ & $\begin{array}{r}-90 \\
10 \\
-322 \\
3\end{array}$ & $\begin{array}{r}-95 \\
2 \\
-358 \\
10\end{array}$ & $\begin{array}{r}\geqslant 96 \\
11 \\
\geqslant 359 \\
15\end{array}$ \\
\hline
\end{tabular}

concentrated in those whose GGT values were in the upper quintiles of the distribution of values among the whole population screened. A similar correlation did not exist for other values commonly regarded as risk factors (table V), though there was a slight tendency for those who died to have serum urate values in the upper quintiles; urate concentrations may also correlate with alcohol consumption. ${ }^{4}$

\section{Discussion}

In this unselected population of Swedish urban men alcohol was the most important single factor associated with death at about the age of 50: an alcohol-positive history was present in over half the men who died. Our study was a short-term prospective study of mortality in a fairly large population, uniform for age and sex, who were invited for screening and followed for up to four years (median two years). Our analysis of alcohol consumption was partly prospective and partly retrospective.

Many studies have confirmed the general impression that alcoholics have increased morbidity and mortality, ${ }^{125-8}$ and such features should also be identified in population studies. Nevertheless, few population studies have been performed because of the difficulties of measuring alcohol consumption. Reliance on self-reported consumption in questionnaires makes findings open to doubt. At our screening investigation we used a modified Michigan alcoholism screening test, ${ }^{3}{ }^{4}$ but we also used a biochemical index of heavy alcohol consumption.

With methods partly comparable to ours Tibblin studied 2992 men living in Gothenberg who were born in $1913 . .^{5-7} \mathrm{He}$ found that of the 273 who died aged $35-5517 \%$ were heavy drinkers or died from alcohol-related conditions. ${ }^{7}$ Lannerstad examined 49 deaths that occurred among 802 men in Malmö at the age of 55-60 years; in $27 \%$ he found signs of alcohol abuse, defined as registration at the alcohol clinic or a blood alcohol concentration at necropsy of more than $22 \mathrm{mmol} / 1$, or both. ${ }^{8}$ The American epidemiological studies in Framingham and at Chicago Western Electric Company also showed an association between alcohol consumption and all causes of death, ${ }^{910}$ but comparisons are difficult because these populations were selected and the ages were different.

Serum GGT activity has been shown in series of alcoholics ${ }^{11-13}$ and in population studies ${ }^{44-17}$ to be the best single biochemical index of high alcohol consumption. Nevertheless, the clinical significance of raised activities has still not been assessed. Measurement of GGT activity may play a useful part in screening investigations for alcohol abuse, especially in middleaged men. We have already shown that $75 \%$ of those with raised GGT values can be classified as heavy users of alcohol. ${ }^{4}$ Our present results illuminate the question of clinical significance by showing that the risk of dying was six to seven times greater in men with GGT values in the highest quintile than in those with values in the lowest quintile. It remains to be seen whether the heavy consumer of alcohol with a normal serum GGT value on screening has a better outlook.

Interestingly, a high serum cholesterol value appeared to be an inverse risk factor for premature death-a finding supported by other reports. ${ }^{818}$ In a mortality study with a short followup such as ours some individuals may have already been ill and in poor nutritional state at the time of the examination, but the relationship between cholesterol concentration and premature death merits further consideration. It is hard to evaluate the role of smoking in our cohorts; $70 \%$ of the 41 attenders who died were smokers, and they were concentrated in the subgroup with a history of heavy alcohol consumption. This probably reflects the known association between alcohol consumption and smoking.

An assessment of drinking habits is a relevant aim in population investigations of middle-aged men, and measurements of serum GGT may help if coupled with a clinical evaluation and treatment programme. Although our observations on shortterm mortality permit no certain general epidemiological conclusions at this stage, we think that our findings are clear and relevant and carry important implications for prevention. 
This study was supported by the Swedish Council for Planning and Co-ordination of Research (BP) and the Swedish Delegation for Social Research, Ministry of Health and Social Affairs (HK).

\section{References}

${ }^{1}$ Straus R. Alcohol abuse and physicians' responsibility. Arch Intern Med 1977;137:1513-5.

${ }^{2}$ Lieber CS. A public health strategy against alcoholism and its complications. Am 7 Med 1978;65:722-6.

${ }^{3}$ Selzer ML. The Michigan alcoholism screening test (MAST): the quest for a new diagnostic instrument. Am $\mathcal{F}$ Psychiatry 1971 ;127:1653-8.

4 Kristenson H, Trell E, Fex G, Hood B. Serum gamma-glutamyltransferase: statistical distribution in a middle-aged male population and evaluation of alcohol habits in individuals with elevated levels. Prev Med 1980;9:108-19.

5 Tibblin G. High blood pressure in men aged 50. Acta Med Scand (Suppl) $1967 ; 470$.

- Tibblin G. Alkohol som riskfaktor för sjukdom och död. Läkartidningen $1974 ; 71: 2053-5$.

7 Tibblin G, Wilhelmsen L, Werkö L. Risk factors for myocardial infarction and death due to ischaemic heart disease and other causes. Am f Cardiol $1975 ; 35: 514-22$.

8 Lannerstad O. Död och sjukdom bland medelålders män. Thesis. Studentlitteratur (Lund) 1978.
${ }^{9}$ US Secretary of Health, Education and Welfare. Second special report to the US Congress on alcohol and health. Washington: US Department of Health, Education and Welfare, 1974. (Preprint edition.)

10 Dyer RD, Stamler J, Paul O, et al. Alcohol consumption, cardiovascular risk factors and mortality in two Chicago epidemiologic studies. Circulation 1977;56:1067-74.

${ }^{11}$ Rosalki SB, Rao D. Serum gamma-glutamyltranspeptidase activity in alcoholism. Clin Chim Acta 1972;39:41-7.

12 Rollason JG, Pincherle G, Robinson D. Serum gamma-glutamyltranspeptidase in relation to alcohol consumption. Clin Chim Acta 1972;39:75-80.

${ }^{13}$ Wu A, Slavin G, Levi AJ. Elevated serum gamma-glutamyltransferase (transpeptidase) and histological liver damage in alcoholism. $\mathrm{Am} \mathcal{F}$ Gastroenterol 1976;65:318-23.

14 Whitehead TP, Clarke CA, Whitfield AGW. Biochemical and haematological markers of alcohol intake. Lancet $1978 ; \mathrm{i}: 978-81$.

${ }^{15}$ Whitfield JB, Hensley WJ, Bryden D, Gallagher H. Some laboratory correlates of drinking habits. Ann Clin Biochem 1978;15:297-303.

${ }^{16}$ Bagrel A, d'Houtard A, Gueguen R, Siest G. Relation between reported alcohol consumption and certain biological variables in an "unselected" population. Clin Chem $1979 ; 25: 1242-6$.

17 Kondo H, Hashida M, Momotani H. Serum gamma-glutamyltranspeptidase as a diagnostic aid in the periodic health examination. Sangyo Igaku 1976;1:95-100.

18 Beagelhole R, Foulkes MA, Prior IAM, Eyles EF. Cholesterol and mortality in New Zealand Maoris. Lancet $1980 ; 1: 285-7$.

(Accepted 6 March 1980)

\section{Summary and conclusions}

Twelve patients aged over 70 with primary hyperparathyroidism (persistent hypercalcaemia and raised serum parathyroid hormone concentrations) underwent parathyroidectomy, which was well tolerated by all. After operation serum calcium concentrations returned to normal and the commonest symptoms before operation (muscle weakness, malaise, and mild to severe dementia), although not related in severity to the degree of hypercalcaemia, improved. Mental function was greatly improved.

The findings suggest that primary hyperparathyroidism should be sought in any elderly patient with hypercalcaemia and that more such patients with the diagnosis should be considered for parathyroidectomy irrespective of age.

\section{Introduction}

Biochemical screening detects many cases of hyperparathyroidism that would otherwise go unrecognised. Most show no evidence of bone disease or renal disease. The commonest group of patients with hyperparathyroidism presenting at our

Queen Elizabeth Hospital, Birmingham B15 2TH

D A HEATH, $M B$, FRCP, reader, university department of medicine A D BARNES, MB, FRCS, consultant surgeon

\section{General Hospital, Birmingham B4 6NH}

A D WRIGHT, MB, MRCP, senior lecturer, university department of medicine G D OATES, MB, FRCs, consultant surgeon

N J DORRICOTT, MB, FRCs, consultant surgeon clinics complain of muscle weakness, tiredness, and general malaise. The next commonest group are patients who appear to be completely asymptomatic but in whom hypercalcaemia is found by chance during investigations for other problems. With the increased recognition of the disease, many elderly patients have been found to have hyperparathyroidism. In such patients the non-specific nature of the symptoms may readily be attributed to "aging," and the decision to operate may be difficult. We report our experience of parathyroidectomy in 12 patients aged 70 or over, which encourages us to recommend operations in symptomatic patients in this age group.

\section{Patients, methods, and results}

The table gives the details of the 12 patients. The commonest symptoms were muscle weakness, mental slowing, and decreased mobility. Before operation, three of the patients (cases 2, 7, and 8) were unable to manage at home and were awaiting long-term hospital care, while two others (cases 5 and 11) were able to live at home only because of considerable attention from relatives living in the same house. Another patient (case 6) had been transferred to sheltered accommodation before operation. In all 12 patients the hypercalcaemia was discovered during routine biochemical investigations for assessment of deteriorating physical state or for completely unrelated medical problems. Hyperparathyroidism was diagnosed when persistent hypercalcaemia was present with raised serum parathyroid hormone concentrations. No patient showed radiological evidence of the disease. At operation a single parathyroid adenoma was found in all cases except case 10, in which two adenomas were removed at separate operations. Successful removal of the adenomas was associated with rapid return of the serum calcium concentration to normal. The operation was well tolerated by all the patients, and no serious complications occurred. Only one patient (case 5) developed severe symptomatic hypocalcaemia. Although mild asymptomatic hypocalcaemia often occurred after operation, all patients eventually achieved normocalcaemia without long-term treatment with calcium supplements or vitamin D. 